\title{
ARE LIBRARIES SUSTAINABLE IN A WORLD OF FREE, NETWORKED, DIGITAL INFORMATION?
}

\author{
Lluís Anglada
}

Nota: Este artículo puede leerse traducido al español en:

http://www.elprofesionaldelainformacion.com/contenidos/2014/nov/07_esp.pdf

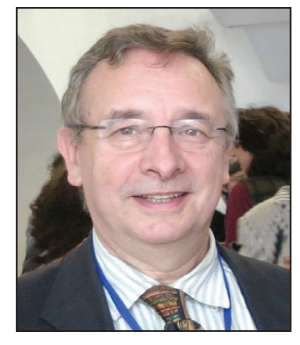

Lluís Anglada is the director of the Department of Libraries, Information and Documentation of the Consortium of University Services of Catalonia (CSUC) after having been the director of the Consortium of Academic Libraries of Catalonia (CBUC) from 1997 to 2013. Previously he was director of the libraries of the Polytechnic University of Catalonia and professor at the Jordi Rubió $i$ Balaguer School of Library and Information Science at the University of Barcelona. He holds a degree in philosophy and a diploma in library and information science. He was a member of the OCLC Global Council and currently is part of the Liber Executive Committee. He is the author and promoter of Blok de Bid and Bdig blogs. He regularly delivers lectures and workshops and publishes articles on libraries and library consortia.

http://orcid.org/0000-0002-6384-4927

Consortium of University Services of Catalonia Gran Capità, 2-4, Nexus bldg., 4th floor. 08034 Barcelona, Spain langlada@gmail.com

\begin{abstract}
The evolution of libraries through three stages -modernization, automation and digitization- is analysed. A formula is presented to evaluate the importance of libraries to our society, and it is applied both retrospectively and futuristically, extrapolating a 2030 scenario. The conclusion is that if the current generation of librarians does not introduce radical changes in the role of libraries, their future is seriously threatened.
\end{abstract}

\section{Keywords}

Analysis, Sustainability, Values, Roles, Functions, Libraries, Extrapolation, Future developments, Prospects, Trends, Forecast.

Título: ¿Son las bibliotecas sostenibles en un mundo de información libre, digital y en red?

\section{Resumen}

Se analiza la evolución de las bibliotecas en sus tres etapas de modernización, automatización y digitalización. Se presenta una fórmula para evaluar el grado de interés que las bibliotecas tienen para la sociedad, y se aplica tanto retrospectivamente como para extrapolar el posible escenario del año 2030. Se concluye que si la generación actual de bibliotecarios no es capaz de introducir cambios radicales en el papel de las bibliotecas, su continuidad está seriamente amenazada.

\section{Palabras clave}

Análisis, Sostenibilidad, Valor, Rol, Funciones, Bibliotecas, Extrapolación, Futuro, Evolución, Perspectivas.

Anglada, Lluís (2014). "Are libraries sustainable in a world of free, networked, digital information?". El profesional de la información, v. 23, n. 6, November-December, pp. 603- 611.

http://dx.doi.org/10.3145/epi.2014.nov.07

\section{Introduction ${ }^{1}$}

Sustainability is the capacity to endure over time. Libraries are among the institutions with the greatest longevity in our society, but the great technological changes that have affected them, especially since the advent of the internet and the digitization of information, have led many researchers to wonder about the future of libraries and whether such institutions continue to make sense. Recent studies include
Blumenthal (2014), Kamat and Pujar (2014), Inouye (2013), Lewis (2013), Rasmus (2013), Cassi (2012), Coffman (2012), Dempsey (2012b), Laudano et al. (2012), Lynch, Greifeneder and Seadle (2012), Varela-Prado and Baiget (2012), Powell (2010), Dillon (2008). The professional community began to worry when several studies (Housewright et al., 2013) showed that users are now much more autonomous than before to seek information on their own, allowing them to dispense with using the library to meet their information needs. 
The sustainability of libraries can be evaluated according to the relationship established between the values added and their costs. Their physical persistence has been associated with physical documents, and particularly with printed books (Gauder, 2010), but our society is rapidly moving to an environment in which the information will be -or already is- primarily digital, probably more fragmented and flowing freely in the Network (Dempsey, 2012; Dillon, 2008). In an environment in which the object perceived as most associated with libraries -the printed book- tends to disappear, will the libraries that have preserved and made available those printed books to whoever wanted to use them also disappear?

The sustainability of libraries can be evaluated from the relationship established between the values added and their costs

This paper aims to present a reflective exercise on the factors that make libraries interesting and attractive to the society that funds and sustains them. The first version of these ideas was presented at the Bobcatsss conference (Anglada, 2014). In the following sections, a mathematical formula is proposed that reveals the sustainability of libraries in
varios historical periods based on the values assigned to
its variables. The formula -which has explanatory and re-
flective, but not scientific, pretensions-, makes it possible
to determine, depending on the historical stage, if libraries
are sustainable, i.e. if their social value exceeds their cost.
The final result is highly correlated with the-perception of the library as an institution, and we can conclude that the

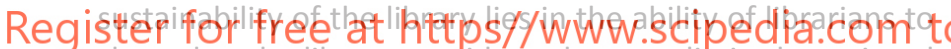
show that the library provides values not limited to printed books or to physical documents.

\section{Methodology: the sustainability formula}

The proposed formula for the sustainability of libraries is the following:

Sustainability $=$ - Value $\frac{\text { Use }- \text { Dysfunctions }+(2 * \text { Perception })}{\text { Cost }}$

Or, in an abbreviated form: $S=(U-D+2 P) / C$

Of course, this formula is not intended to be an expression of an exact law such as those of physics; it is rather a pretext, an intellectual exercise or an academic amusement (whatever you want to call it), which helps us to make a serious analysis of the role of libraries in society. While we can easily understand the use (U) of libraries, we must specify what we mean by dysfunctions (D): we can define them as unfulfilled expectations, a contrast between expectations and reality $(E-R)$. In the proposed exercise, variables can be assigned values between 1 and 5 , in the most objective way possible considering each stage or historical moment. Inevitably, the assignment of values to variables always has a significant degree of subjectivity, but here we have based these values on facts and actual situations, duly reported in the professional literature.

Another methodological note before continuing. A division of the recent history of libraries into three major phases over the past 50 years is proposed:

- Mechanization, a period characterized by the construction of new buildings and mechanization of processes;

- Automation, in which networks of libraries were created, OPAC was introduced and union catalogues were created; and

- Digitization, in which electronic journals and books appeared and documents stored in libraries have been digitized (Buckland, 1992) ${ }^{2}$.

We set off from the hypothesis that the same stages and library events have taken place in all countries and in all library types, but not at the same time. Therefore, the different phases that libraries passed through to become automated are similar in each country, but they occurred in different years (Anglada, 2006).

\section{Recent values assigned to the library sustainability formula}

\subsection{Mechanization stage}

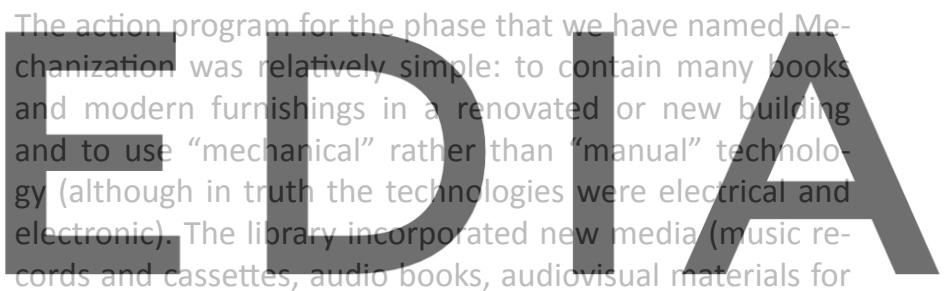

teaching, etc.), microformats were used to increase collec-

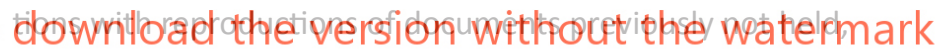
and technological innovations helped to modernize services (photocopiers for document delivery, telex and later fax to send interlibrary loan requests).

The Mechanization phase of library modernization that developed in Europe during the '60s -but did not reach Spain until the end of the '70s- assumed generally that libraries were the only place where everyone could find information (and besides for free). Public perception was highly positive and the operating cost was relatively low. In these circumstances, we estimate the values of the variables in the formula as follows: fairly high usage $(U=4)$, no dysfunctions because no one expected anything specific from libraries ( $D$ $=0)$, very good user perception $(P=4)$ and relatively low cost to funders $(C=3)$. The result of applying the sustainability formula $(S=4)$ argues that the sustainability of the modern (1970) mechanized library was high:

$$
\mathrm{S}(1970)=(\mathrm{U}-\mathrm{D}+2 \mathrm{P}) / \mathrm{C}=(4-0+2 * 4) / 3=12 / 3=4
$$

\subsection{Automation stage}

This stage, which could also be called the computerization stage, is defined by the use of computers in libraries, which occurred experimentally in the early '70s and was definitively introduced in the '80s (Anglada, 2006). Libraries created networks (like OCLC) or cooperatives (PICA in Holland, 
Scolcap in Scotland...) or national centres (Bibsys in Norway) to share the high costs of computers at the time. National or regional union catalogues were created, interlibrary loan agreements were put in place, and eventually commercial programs for integrated management (integrated library systems, ILS) became available. Thus libraries began to offer online access to databases (Baiget, 1998), online public access catalogues (OPACs) were launched, and CD-ROMs were introduced.

In this stage, librarians were the protagonists -30 or 40 years ago they were young people applying "new technologies" to library services at all times: electric typewriters to duplicate catalogue cards or CD-ROMs to provide ac-

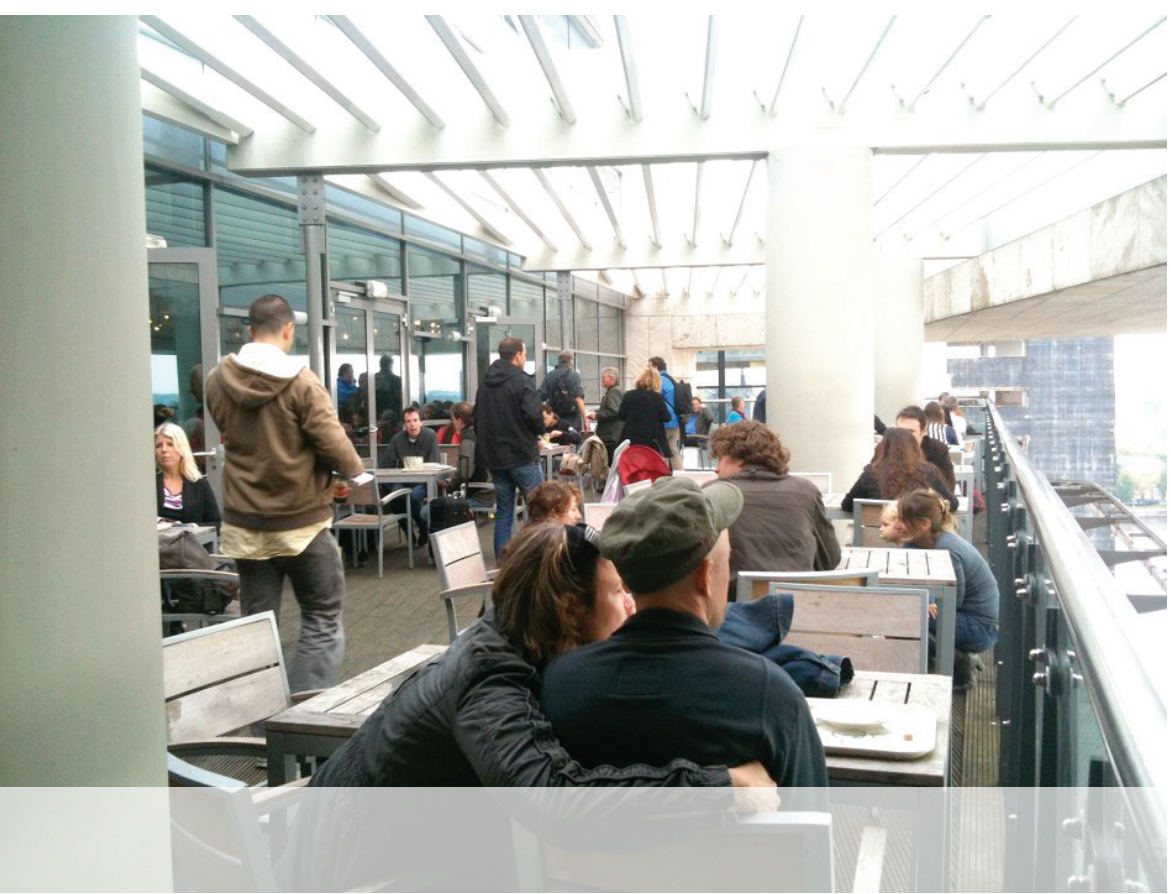

Figure 1. Less space for books and more for people (Amsterdam Public Library) cess to bibliographic information. If, as it has been said, the main steps of library automation occurred in the 70s and 80 s in the developed world, in a As in the past, librarians have been proactive in the face of spain that was coming out of the France era the change oc

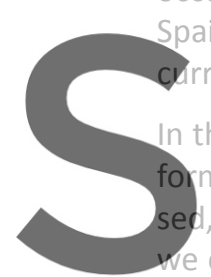
rred about 10 years later.

the '90s, libraries were stil th mation, and although the they were still not overly can say that the library auto
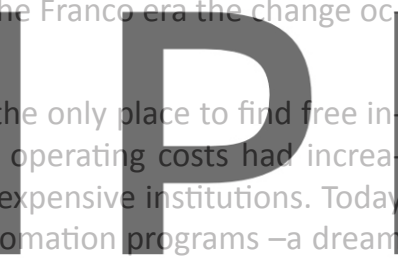

that once seemed far-off in the future- are virtually ubiquichange and have been able to create new uses for libraries.
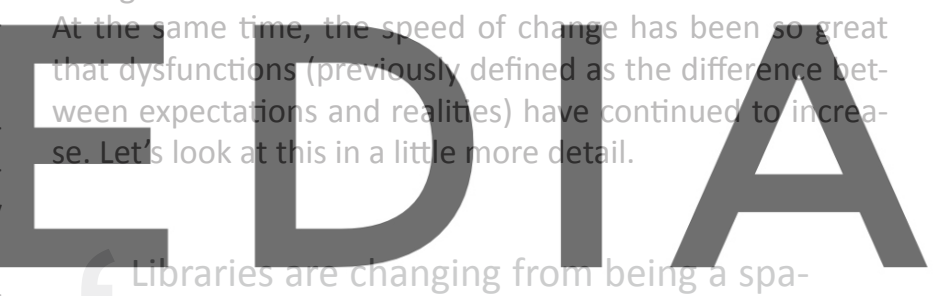

Let's assign values to the formula for this period: fairly high usage $(U=4)$, some dysfunctions due to technological limitations $(D=1)$ as, for example, online searches of remote databases incurred costs associated with connection time, as well as expensive and complicated telephone connections (Baiget, 1998). User perception was still good $(P=4)$ as they experienced improvements, but the cost was considerably higher due to the essential computer technology (C $=4)$. The result of applying the formula to the automated library of this stage still yields an acceptably high value $(\mathrm{S}=$ 2.75), although lower than that of the preceding stage.

$$
\mathrm{S}(1990)=(\mathrm{U}-\mathrm{D}+2 \mathrm{P}) / \mathrm{C}=(4-1+2 * 4)=11 / 4=2.75
$$

\subsection{Digitization stage}

The third stage began its development between the late $20^{\text {th }}$ and early $21^{\text {st }}$ century. The digitization stage, like all others, is characterized on the one hand by a disruptive innovation (Internet) and, on the other, by the developments of the preceding stage. It is redundant and obvious to point out that the Internet has caused and still is causing major changes in the way society is organized and people interact, but perhaps it is less evident that these changes are so recent that we cannot yet know how they will be consolidated.
We can start with the positive aspects, the legacy that our generation has been able to build. Starting with modernized/mechanized and computerized/automated libraries, librarians have explored new uses for library buildings and new roles for the profession. It is never easy to recreate the functionality of a space that has well-established applications, and even less easy to do so when these spaces are newly created. Perhaps the most intense changes have occurred in the public libraries, which were created as places for quiet, lonely, individual work and study, and today are offered as meeting places for socializing and sharing and active learning. Libraries are changing from being a space to store, locate and use books to places where people interact and socialize. This should transform the perception that citizens have of their libraries, seeing them as places to 'change lives by giving people the tools they need to succeed'3.

Recent professional literature has shown that the contributions of the public library are not limited to lending books. In economic crises, libraries emphasize their role in helping people (Gauder, 2010), fighting the digital divide by offering culture, entertainment and Internet connectivity for 
all (Vinjamuri, 2014; Fleck, 2013, Houghton et al., 2014.; Goedekena, 2014), or contributing to the creation of social cohesion and impartial public spaces (Jochumsen et al., 2012; Vårheim et al., 2008).

The fact that libraries carry out functions of assistance and intermediation that do not produce final results impose on them a permanent invisibility; this is very negative because they depend on public funding, and their future depends on the perception or mental image of libraries held by administrators and policy makers who allocate budgets (Varela-Prado; Baiget, 2012). Therefore, the efforts that libraries made in the past to show statistical data on resources ("holdings") and usage ("circulation data") must now show the value that libraries have for the entities that support them financially (Oakleaf, 2012; Gómez-Yáñez, 2014, Paños-Paños, 2011) and for the citizens who use them (Vakkari; Serola, 2012; Huysmans; Hillebrink, 2008).

\section{The fact that libraries carry out functions} of assistance and intermediation that do not produce final results impose on them a permanent invisibility

University libraries, meanwhile, have seen that their modernized buildings and computerized collections are not suffi-

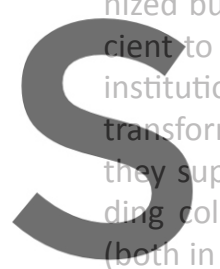
continue to attract user a intitutions. This has led, on the ransformation of the space but alsc upport research. Tradition methods and in practicel $h$ and to be useful to vheir
so to changes in the ways
y this was done by buil-
scientific communication
neve required libraries to reorganize services and more actively support researchers.

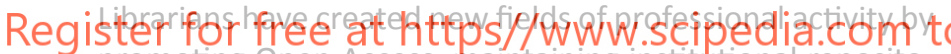
promoting Open Access, maintaining institutional repositories, helping researchers to make their work more visible on the internet, facilitating the adoption of identifiers for authors and for documents, etc. Other areas in which the profession has created new activities include information literacy, digitization of resources and the creation of digital libraries (such as Memòria Digital de Catalunya) and portals (such as Europeana or DART-Europe) using a federated distribution of tasks and the adoption of standards...

We have tried to show that the problem of libraries is not immobility, as they have resilience and ability to adapt to new environments. At a time of profound change they have known how to reorient and to propose new options that create new uses. But the emergence of new roles for libraries does not mean that all library services have evolved over time.

Previously we defined dysfunctions as unfulfilled expectations, as the difference between the expected and the reality. ${ }^{4}$ We have accumulated too many dysfunctions. Some are economic and make libraries less competitive (Coffman, 2012; Dempsey, 2012, Lewis, 2007); others are related to service design and make them less useful. I will not dwell too much on these dysfunctions but will mention three examples:
- How many times is the same book catalogued? More than once is too many. Librarians spent decades developing common cataloguing standards and practices, and standards for data transmission, but this has not prevented the same document from being catalogued by several people in different ways. While the former "only" has economic impact, the latter generates duplications in catalogues, resulting in system recovery failures.

- Library catalogues and automated systems were innovative in the ' 80 s, but have been stuck in outmoded practices. Users have adapted quickly to the 'googlization' of information and do not understand why they should have to look in different places to get a unique solution to an information need.

- Finally, despite the many social changes in recent decades, libraries have not sufficiently adapted their services to new expectations. Library hours should better respond to citizens' nonwage and festive days, as well as adapting to this new form of communication that is social networking.

Given these considerations, we can assign values to the present moment. The usage is still quite high $(U=4)$ even though the library is no longer seen as the only place to find (free) information. As we have seen, dysfunctions increased $(D=2)$ and also increased the technology promises that cannot be met in the library at an everyday level. Perception is

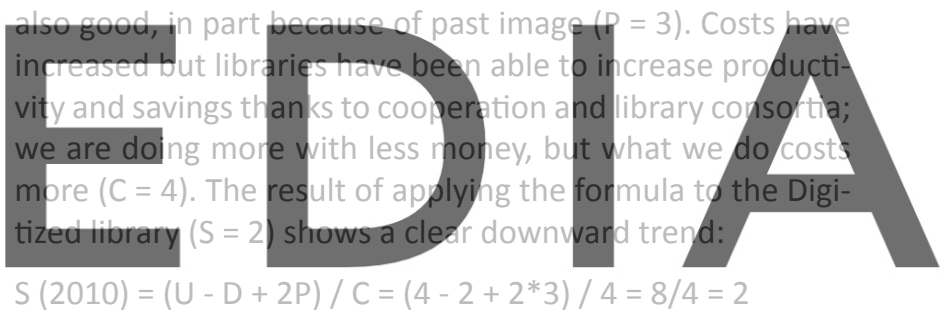

\section{dowaload the versipquwithput the watermark} sustainability: perception and adaptation to a new paradigm

Two of the elements involved in the formula -costs and useare fairly intuitive, but we have to justify the introduction of the element of 'perception' and the importance we assigned to it. Daniel Kahneman received the 2002 Nobel Prize in economics for showing, along with Amos Tversky, that many of the decisions people take are not based on probability calculation or reason but on cognitive biases or prejudices. These biases or stereotypes construct perceptions that are not always grounded in reality. In the words of Kahneman (2011, ch. 16, p. 223):
"When the categories are social, these representations are called stereotypes. Some stereotypes are perniciously wrong, and hostile stereotyping can have dreadful conse- quences. But the psychological facts cannot be avoided: stereotypes, both correct and false, are how we think of categories."

The contributions of cognitive psychology indicate that people make decisions motivated by mental frames (Lakoff, 2004) or perceptions, and not only by the facts or reality. This is also apparent in an OCLC study (De-Rosa; Johnson, 2008; Anglada, 2008) showing that the predisposition to 
vote for taxes to create libraries has little to do with their actual use:

\begin{abstract}
"Significantly and surprisingly, library funding support is not driven by demographics, i.e., income, age, gender, race, political affiliation, etc.
\end{abstract}

[...] Library support is more about a mindset or an attitude than a traditional demographic profile".

However, the general public mental image (perception) of libraries was forged over decades and, although they have pioneered ample use of new technologies, the image of libraries remains attached to the printed book. In 2005, 69\% of Americans had this perception (De-Rosa, Cantrell, OCLC, 2005), and it had increased to 75\% in 2010 (Gauder, 2010, p. 39).

In the past, this perception of the libraries gave them a high social value because the printed book was the only means of disseminating information and recording culture, and the library -a books warehouse- received the same value associated to information and culture. ${ }^{5}$ The development of the Internet has established a dissociation between the information itself and its supporting document. Information flows in the Network independent of its support, and its access cost (in user time and money) does nothing but decrease.

In the print world (which we are leaving) the public perception equating libraries with books was positive for libraries

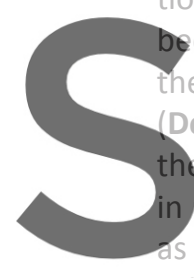
ecause books, or rather access
e user's time to access the i
Dempsey, 2012). The change
carrier, but in the huge, nearly free
he Network. The information
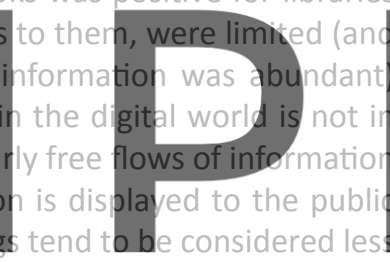

plentiful, and abundant things

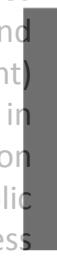

What is the first thing you think of when you think of the library?

\section{Books}

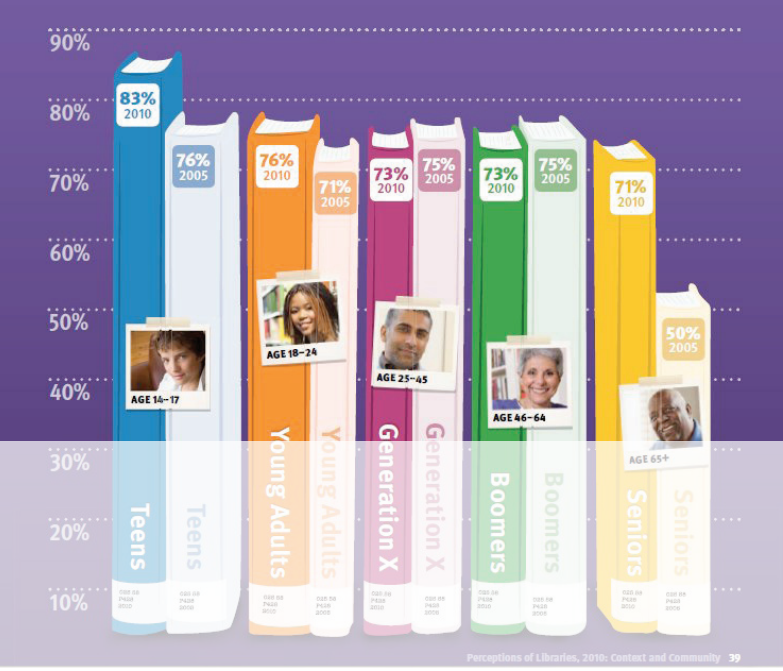

Figure 3. OCLC. Perceptions of libraries: context and community, p. 39. http://www.oclc.org/reports/2010perceptions/2010perceptions_all_ singlepage.pdf

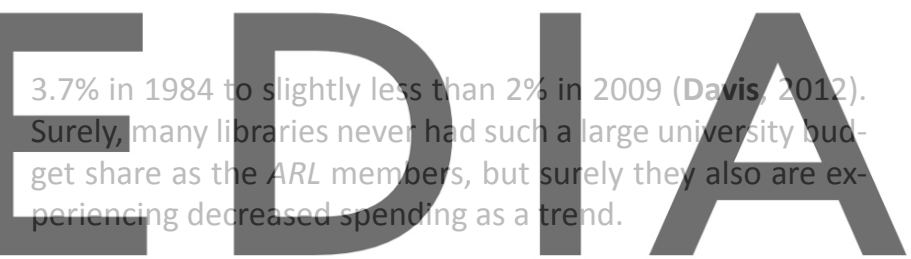

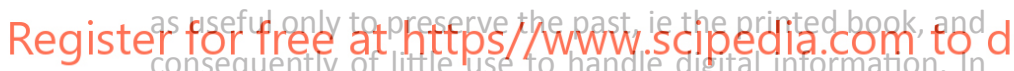
the new environment, some traditional strengths of libraries are weakening.

The library has been steadily declining in importance in university budgets. According to the annual reports of 40 members of the American Research Libraries ( $A R L)$, the percentage of university spending in libraries decreased from

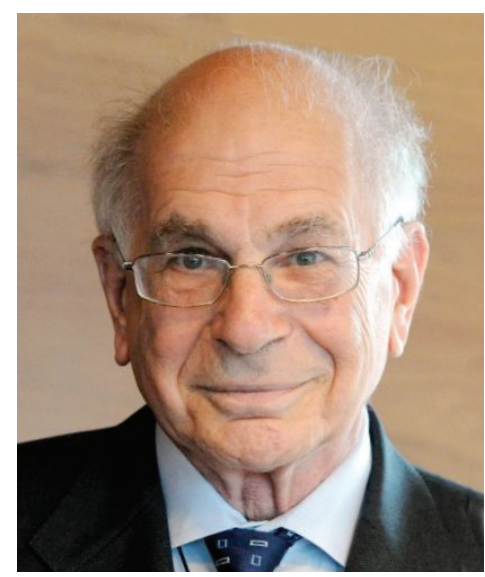

Figure 2. Daniel Kahneman: People's decisions are motivated by perceptions and not only by the reality

At the same time, some classic library services are experiencing significant declines. Annual statistics from the Association of College and Research Libraries (ACRL) show a decrease of more than $30 \%$ in loan transactions between 1998 and 2008. In the same period, the decline was significantly greater in reference inquiries made to librarians, a service traditionally associated with the university library (University Leadership Council, 2011).

Several studies have indicated a displacement of the starting point for literature searches. While the physical library or its catalogue were the classical mode, between 2003 and 2012 both lost importance in comparison with beginning searches in Internet search engines or specialized databases (Housewright, 2013). A recent survey of teachers and researchers from the universities of Catalonia showed that half of the respondents went first to a specialized database to start a literature search; the second option was Internet search engines (30\%), followed by the library catalogue $(17 \%)$ and the option of physically visiting the library, a residual 3\% (Borrego, 2014). 


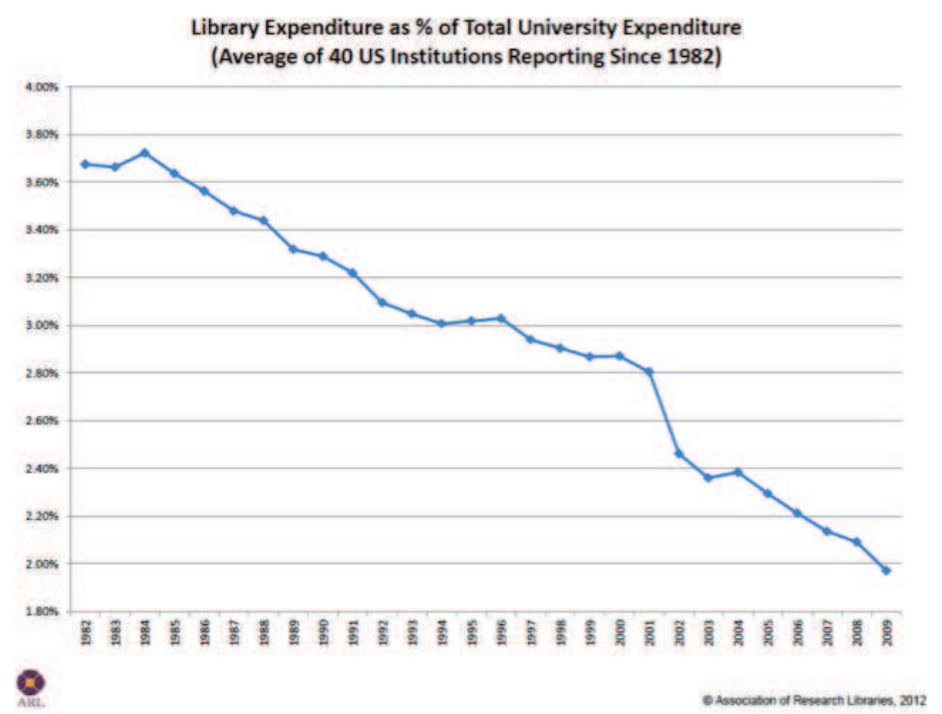

Figure 4. Library expenditure as \% of total university expenditure (average of 40 US institutions reporting since 1982). Association of Research Libraries.

We can summarize the current situation as a complex framework in which libraries have been able to play new roles, although they could not prevent the existence of dysfunctions. The key element, however, is the perception that libraries are associated with the print world, giving rise to

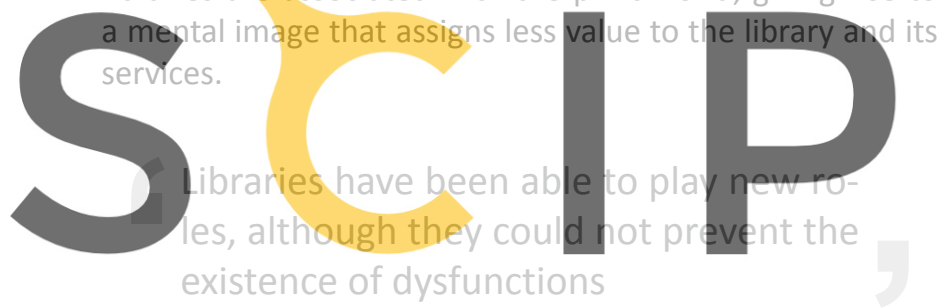

Register for free at https//www.scipedia.com to

\section{Are libraries sustainable in a world of free, networked, digital information?}

Let's imagine that 15 years have elapsed and we are making a trip to a library in 2030. We ask one of the librarians to calculate the $S$ value for 2020 .

That librarian of the future will probably tell us that in 2020 a large part of the professional and scientific journals were already available for free in digital format, there was a lot of quality information on the Internet, services provided through the Net were better than those provided by libraries, and libraries were becoming marginal resources with very high costs. The values of the variables could be: $U=$ $3, D=2, P=2, C=4$, with a result of $S=1.25$-namely, low sustainability.

$$
S(2020)=(U-D+2 P) / C=(3-2+2 * 2)=5 / 4=1.25
$$

What if we asked our librarian to tell us about the situation in 2030? Perhaps we would hear that open access is a complete reality in the scientific world, that many services provide access to scientific, literary, promotional and leisure works for a clearly acceptable flat fee, and that Google's successor finds needed documents with almost no margin of error... In this situation, the library stands as a resource with relatively high marginal costs. Let's assign values: uses declining $(U$ $=2)$, a similar degree of dysfunction ( $D=2)$, low perception of usefulness $(P=1)$, and costs remain stable $(C=4)$. The value of $S$ -less than one- indicates that libraries are unsustainable.

$\mathrm{S}(2030)=(\mathrm{U}-\mathrm{D}+2 \mathrm{P}) / \mathrm{C}=(2-2+2 * 1)=$ $2 / 4=0.5$

Examining our recent past more closely, we can see that libraries have had some ability to reinvent themselves (participating in open access or information literacy, for example), attracting new uses. Costs have been contained by creating networks and consortia, and making joint purchases. They have had less influence in changing how society perceives them. It is difficult to accept the paradox that, while the public is fully immersed in the Information Society, the information professional is ignored. The name of the profession -'librarian'- inevitably confines it to what its name suggests: the four walls of the library ${ }^{6}$.

The generation that started the modernization and auto-
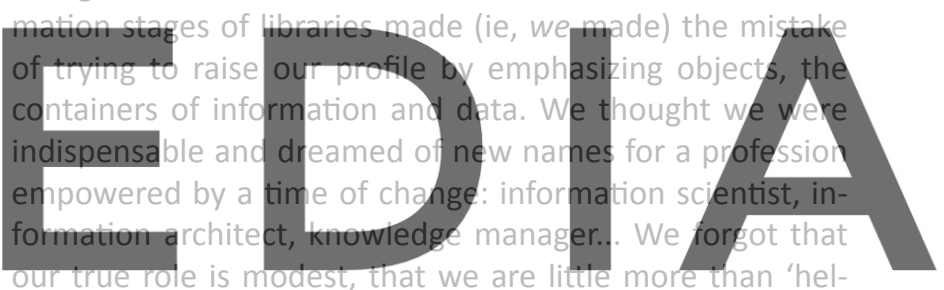

pers $^{17}$ in Infoland, a world of abundant and free-flowing domaitioad thiehversitens withojat therescatermark although still important.

Rephrasing the title question: Who sustains libraries and why? Libraries are sustained by people through institutions and society in general because they believe, feel, intuit or think that libraries are important to them, because they have a positive perception of them. With the aforementioned studies seeking to show the added value of libraries, we can influence the rational thinking of citizens but changing their perception of libraries requires that we address their emotions.

But, are libraries really important to people? And how about the professionals who work in and out of them? Yes, we represent a unique point of view regarding information. We are not interested in the results (to get information), but in the process (to help people to find and use it). We do not want just any information (the most used) or only some users (those who can best use it): a library (the organization, not the building) seeks to collect and preserve all information for all and forever (Gorman, 2007). The library is closer to the people than to the document, because it seeks to put information at the service of people by providing tools and skills to be citizens (not lackeys) in a world where access to and use of information can be key elements of success or social exclusion. 
We believe that society (still) needs the functions performed by libraries (and librarians), but does this make them immediately sustainable? The answer is no. And it will remain so unless we can soon establish a new stereotype of 'library' in people's minds, one that is not based on the physicality of the buildings or books, but focuses on the role of support and assistance in the difficult process of using information and transforming it into knowledge. The creation of perceptions of a library and librarian that are associated with assistance regarding information is a contribution that has not yet been made.

The creation of this new perception certainly cannot be done by the players who participated in the modernization and automation of the libraries of the late $20^{\text {th }}$ century. It remains to be performed by the current generation of young librarians, those who are inheriting renovated libraries but also a mental image that is associated with becoming less powerful for society. This is the challenge and responsibility for young librarians: to create a new perception of our profession

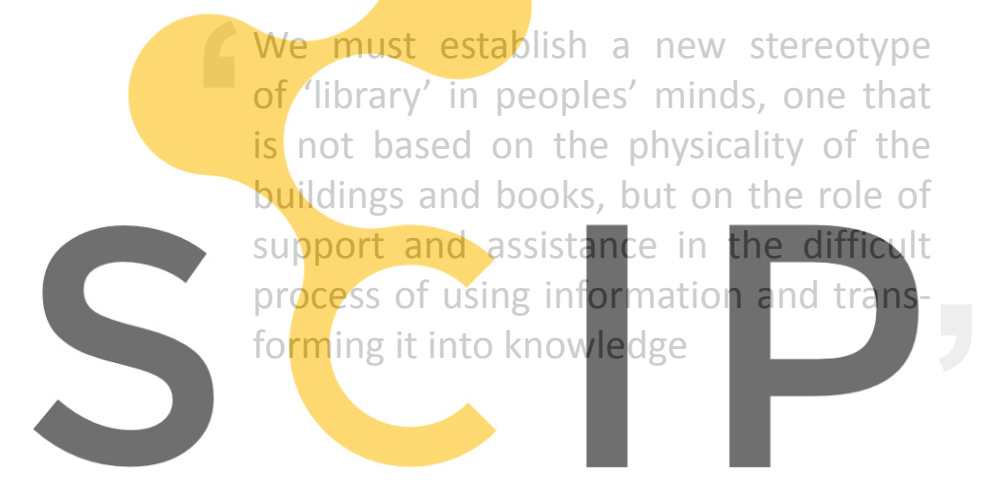

Acknowledgements

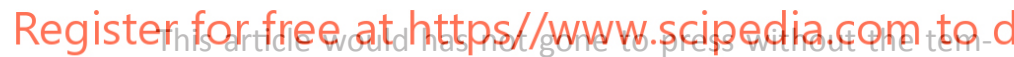

pers, encouragement and aid of Tomàs Baiget who, besides that spiritual companionship, generated the conference transcript. I also want to thank Cristóbal Urbano for reading a previous version of the article, and his on-target comments.

\section{Notes}

1. This article is a transcript and expansion of the inaugural lecture delivered by the author at the $22^{\text {nd }}$ Bobcatsss conference in Barcelona, 29-31 January 2014, which had the motto of Library (r)evolution: Promoting sustainable information practices. Bobcatsss is organized by Library and Information Science students, and this paper was addressed to them.

2. Buckland terminology is 'paper library', 'automated library', and 'electronic library'.

3. 'Libraries: a place that changes lives by giving people the tools they need to succeed', John Szabo, director of Los Angeles Public Library, in: Libraries as a resource in the digital age, post Citizens of culture, Sept. 17th 2014.

http://citizensofculture.com/2014/09/17/libraries-as-aresource-in-the-digital-age

4. Perhaps this definition of "dysfunction" is insufficient.
Cristóbal Urbano proposed the term "friction differential", which would be the difference in the costs of obtaining a piece of information in a library and getting the same information from other agents in the document chain. Thus, $D$ (friction differential) would increase over time in relative terms, not absolute terms: libraries have improved accessibility, availability, etc., but at the same time other agents in the information chain (both commercial and social and collaborative on the Internet) have offered shortcuts and greater flexibility.

5. See, for example, "The one place where books have been free is libraries, whose existence is instructive in another way: We've had libraries for centuries and fund them with public dollars because we view books not just as entertainments, but as repositories of culture and knowledge." Hughes, Evan. "Books don't want to be free: How publishing escaped the cruel fate of other culture industries". New republic, October 8th, 2013.

http://www. newrepublic.com/article/115010/publishingindustry-thriving?utm_content=bufferad667\&utm source=buffer\&utm_medium=twitter\&utm_campaign=Buffer

6. "No one can understand that a 'librarian' can act outside the library, and while this is repeated again and again, stubbornly librarians do not want to leave that label that will marginalize them for life, preventing them, for example, from working in companies that have no library." Conversa-

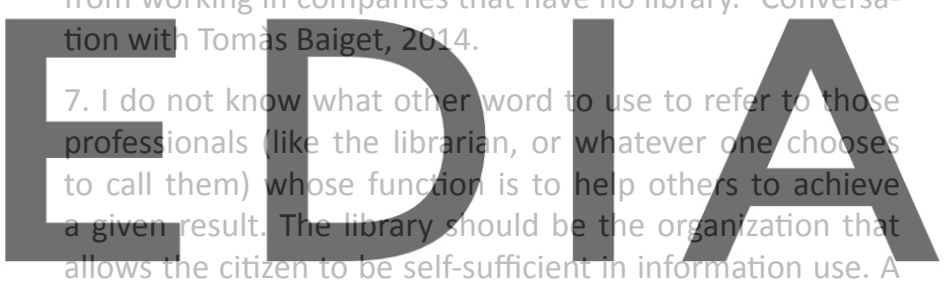

seemingly paradoxical role of the librarian is to become un

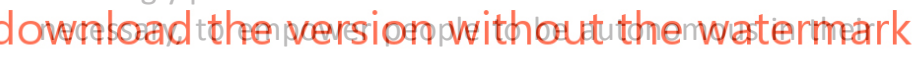
search for the information they need.

\section{Bibliographic references}

Anglada, Lluís (2006). "Veinticinco años de automatización de bibliotecas en Cataluña". BiD: textos universitaris de biblioteconomia i documentació, junio, n. 16. http://bid.ub.edu/16angla2.htm

Anglada, Lluís (2008). “Aprendiendo de Lakoff ¿Quién apoya a las bibliotecas?". BDig, 28 septiembre.

http://bdig.blogspot.com.es/2008/09/aprendiendo-delakoff-quin-apoya-las.html

Anglada, Lluís (2012). "Críticas excelentes, alternativas insuficientes". BDig, lunes, 26 noviembre de 2012 http://bdig.blogspot.com.es/2012/11/criticas-excelentesalternativas.html

Anglada, Lluís (2014). "Are libraries sustainable in a world of free, digital and networked information?" [not published]. In: $22^{\text {nd }}$ Bobcatsss conference. Library (r)evolution: Promoting sustainable information practices. Barcelona, 29 ${ }^{\text {th }}-31^{\text {st }}$ January 2014. http://bobcatsss2014.hb.se

Baiget, Tomàs (1998). "25 años de teledocumentación en España". Revista española de documentación científica, v. 21, n. 4, pp. 373-387. 
http://dx.doi.org/10.3989/redc.1998.v21.i4.359

Blumenthal, Jane (2014). "Creating the future". Journal of the Medical Library Association, v. 102, n. 1, pp. 2-4. http://dx.doi.org/10.3163/1536-5050.102.1.002

Borrego, Ángel (2014). “Comportament informatiu del professorat de les universitats catalanes: estudi realitzat per encàrrec del Consorci de Serveis Universitaris de Catalunya (CSUC)". Barcelona: CSUC: Àrea de Biblioteques, Informació i Documentació (not published).

Buckland, Michael K. (1992). Redesigning library services. Chicago: American Library Association.

http://sunsite.berkeley.edu/Literature/Library/Redesigning/ html.html

Cassi, Marco (2012). "Il futuro della biblioteca accademica di ricerca: alcuni temi chiave". In: Oltre la biblioteca e i bibliotecari: professioni necessarie per la biblioteca accademica di ricerca, Roma (Italia), 5 nov.

http://eprints.rclis.org/17950

Coffman, Steve (2012). "The decline and fall of the library empire". Searcher, v. 20, n. 3

http://www.infotoday.com/searcher/apr12/Coffman--TheDecline-and-Fall-of-the-Library-Empire.shtml

Davis, Phil (2012). "Libraries receiving a shrinking piece of the university pie". The scholarly kitchen, Feb 15, 2012,

\section{http:x/scholarlykitchen.sspnet.or}

piece-of-the-university-pie

Dempsey, Lorcan (2012). "Thirte

ries, discovery, and the catalog:

use review online, Monday

www.educause.edu/ero/art

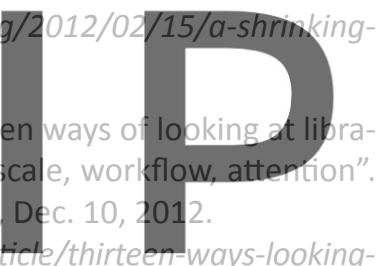

libraries-discovery-and-catalog-scale-workflow-attention

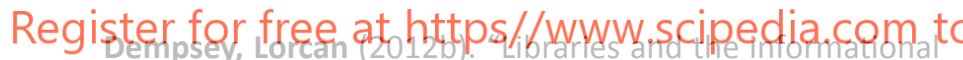

future: some notes". Information professionals 2050: Educational possibilities and pathways, Eds. Gary Marchionini and Barbara Moran (Chapel Hill: School of Information and Library Science, University of North Carolina at Chapel Hill), pp. 113-125. ISBN: 9781300204862

http://sils.unc.edu/sites/default/files/publications/ Information-Professionals-2050.pdf

De-Rosa, Cathy; Johnson, Jenny (2008). From awareness to funding: A study of library support in America. A report to the OCLC membership, $212 \mathrm{pp}$.

http://www.oclc.org/reports/funding/fullreport.pdf

De-Rosa, Cathy; Cantrell, Joanne et al. (2005). Perceptions of libraries and information resources. A report to the OCLC membership, 290 pp.

http://oclc.org/reports/2005perceptions.en.htm/

Dillon, Dennis (2008). “A world infinite and accessible: Digital ubiquity, the adaptable library, and the end of information". Journal of library administration, v. 48, n. 1, pp. 69-83. http://dx.doi.org/10.1080/01930820802035034

Fleck, Alissa (2013). "Libraries bridge digital divide". News our town downtown, July 3rd.

http://nypress.com/libraries-bridge-digital-divide
Gargiulo, Paola (2012). "L'electronic resources librarian tra competenze vecchie, nuove e future". In: Oltre la biblioteca e i bibliotecari: professioni necessarie per la biblioteca accademica di ricerca, Roma, Italia, 5 nov. http://eprints.rclis.org/17947

Gauder, Brad (editor) (2010). Perceptions of libraries: context and community. A report to the OCLC membership. Dublin, Ohio: OCLC. ISBN: 9781556533952

http://www.oclc.org/reports/2010perceptions/2010percept ions_all_singlepage.pdf

Goedekena, Ed (2014). "Digital libraries and information access: Research perspectives". Technical services quarterly, v. 31, n. 2, pp. 210-212.

http://dx.doi.org/10.1080/07317131.2014.875403

Gómez-Yáñez, José-Antonio (coord.) (2014). El valor económico y social de los servicios de información: bibliotecas: Informe de resultados. Fesabid.

http://www.fesabid.org/system/files/repositorio/fesabidvalor-economico-social-servicios-informacion-bibliotecas.pdf

Gorman, Michael (2007). "The wrong path and the right path: The role of libraries in access to, and preservation of, cultural heritage". New library world, v. 108, n. 11/12, pp. 479-489.

http://dx.doi.org/10.1108/03074800710838236

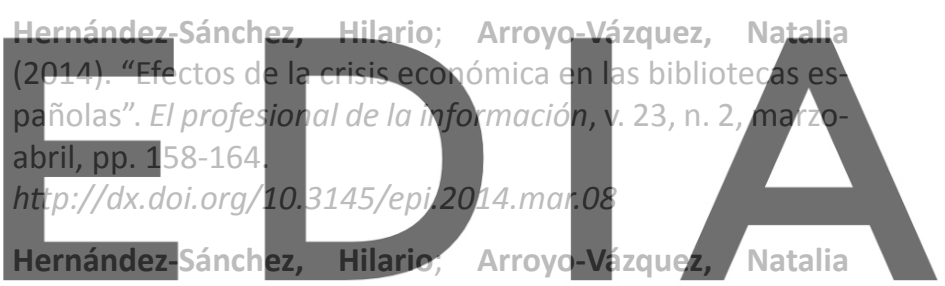

(2012). "Las bibliotecas en España en 2011". Anuario ThinkEPl, v. 6, pp. 48-54.

diejwn wad the version withonth the dwatermark thinkepi-2012

Houghton, Kirralie; Miller, Evonne; Foth, Marcus (2014). "The local library bridging the digital and physical city: opportunities for economic development". Commonwealth journal of local governance (in press).

http://eprints.qut.edu.au/66194

Housewright, Ross; Schonfeld, Roger C.; Wulfson, Kate (2013). Ithaka $S+R$ US faculty survey 2012. New York: Ithaka S+R, 2013.

http://www.sr.ithaka.org/research-publications/us-facultysurvey-2012

Huysmans, Frank; Hillebrink, Carlien (2008). "The future of the Dutch public library: ten years on". The Hague: Netherlands Institute for Social Research.

http://www.scp.nl/english/Publications/Publications_by_ year/Publications_2008/The_future_of_the_Dutch_public_ library_ten_years_on

Inouye, Alan S. (2013). "The future of libraries at thirty thousand feet: strategy and public policy". Young adult library services. Fall, v. 12, n. 1, pp. 9-12.

http://www.questia.com/library/journal/1G1-349902998/

the-future-of-libraries-at-thirty-thousand-feet-strategy 
Jochumsen, Henrik; Rasmussen, Casper-Hvenegaard; SkotHansen, Dorte (2012). "The four spaces - a new model for the public library". New library world, v. 113, n. 11/12, pp. 586-597.

http://dx.doi.org/10.1108/03074801211282948

Kahneman, Daniel (2011). Thinking, fast and slow. Farrar, Strauss \& Giroux. ISBN: 9780374275631

Kamat, Rajanish K.; Pujar, Shamprasad M. (2014). “Inside out and outside in: future legend of library and information science". In: Recent trends in library and information science: a forward for the future. LIS Academy International, pp. 206-216. http://eprints.rclis.org/22730

Kepple, Sarah (2013). "Intentionally backwards, the future of learning in libraries". Young adult library services. Fall, v. 12, n. 1, pp. 33-37.

http://www.questia.com/library/journal/1G1-349903004/ intentionally-backwards-the-future-of-learning-in

Lakoff, George (2004). "Don't think of an elephant!". White River Junction, Vermont, USA: Chelsea Green Publishing, 174 pp. ISBN: 1931498717

Laskowski, Mary S.; Maddox Abbott, Jennifer A. (2014). "The evolution of technical services: learning from the past and embracing the future". Technical services quarterly, v. 31, n. 1, pp. 13-30.

http://dx.doi.org/10.1080/0731 Audano, Claudia-Nora; Planas, (2012). "Un futuro cargado de te cambios imaginables en una década". Palabra clave, tp://eprints.rclis.org/17924
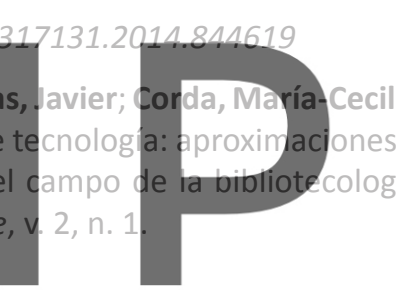

Lewis, David W. (2007). "A strategy for academic libraries

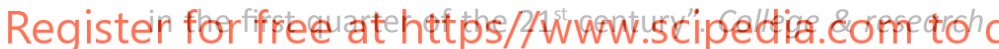
libraries, v. 68, n. 5, pp. 418-434.

http://crl.acrl.org/content/68/5/418.full.pdf

Lewis, David W. (2013). "From stacks to the web: the transformation of academic library collecting". College \& research libraries, v. 74, n. 2, pp. 159-176.

http://hdl.handle.net/1805/3252

Lynch, Clifford; Greifeneder, Elke; Seadle, Michael S. (2012). "Interactions between libraries and technology over the past thirty years: an interview with Clifford Lynch, 23 June 2012". Library hi tech, v. 30, n. 4.

Oakleaf, Megan (2010). The value of academic libraries: $A$ comprehensive research review and report. Chicago: Association of College and Research Libraries.

http://www.ala.org/acrl/sites/ala.org.acrl/files/content/ issues/value/val_report.pdf

O’Connor, Steve (2014). "Leadership for future libraries". Library management. Feb., v. 35, n. 1/2, pp. 78-87.
http://dx.doi.org/10.1108/LM-06-2013-0047

Paños-Paños, Antonio (2011). "Análisis de los beneficios económicos y el perfil de innovación de las bibliotecas públicas". Boletín de la Asociación Andaluza de Bibliotecarios, n. 102 , pp. 65-77.

http://dialnet.unirioja.es/servlet/articulo?codigo $=4004296$

Pattinson, Damian; MacCallum, Catriona J. (2014). "The future is open: opportunities for publishers and institutions". Insights: the UKSG journal, v. 27, n. 1, Mar, pp. 38-44. http://dx.doi.org/10.1629/2048-7754.139

Powell, Allen (2010). "Times of crisis accelerate inevitable change". Journal of library administration, v. 51, n. 1, pp. 105-129.

http://dx.doi.org/10.1080/01930826.2011.531644

Rasmus, Daniel W. (2013). "Uncertainty and the future of libraries". Computers in libraries. Dec., v. 33, n. 10, pp. 4-32. http://paasb.paarchiver.com/infotoday/doc/1468554366.html

University Leadership Council (2011). Redefining the academic library. Washington, DC: Education Advisory Board, November.

Vakkari, Pertti; Serola, Sami (2012). "Perceived outcomes of public libraries". Library and information science research, v. 34, n. 1, pp. 37-44.

http://dx.doi.org/10.1016/j.lisr.2011.07.005

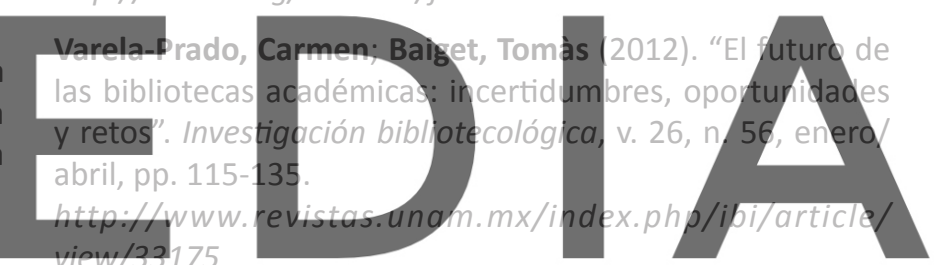

Vårheim, Andreas; Steinmo, Sven; Eisaku, Ide (2008). "Do

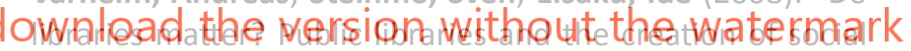
capital". Journal of documentation, v. 64, n. 6, pp. 877-892. http://dx.doi.org/10.1108/00220410810912433

Vinjamuri, David (2014). "How public libraries are solving America's reading problem". Forbes, 11 March. http://www.forbes.com/sites/davidvinjamuri/2014/03/11/ how-public-libraries-are-solving-americas-reading-problem

Walton, Graham (2014). "Will smart phones and other bring your own devices (byod) dominate how academic library services are developed and delivered for the foreseeable future? New review of academic librarianship, Jan., v. 20, n. 1, pp. 1-3.

http://dx.doi.org/10.1080/13614533.2014.875294

Young Adult Library Services Association (Yalsa) (2014). The future of library services for and with teens: a call to action. Institute of Museum and Library Services, Jan., 59 pp. http://www.ala.org/yaforum/sites/ala.org.yaforum/files/ content/YALSA_nationalforum_final.pdf 